\title{
Spain and Pandemic COVID-19: State of Alarm to Climate Lacking in Various Aspects
}

\author{
Spanyol dan Pandemi COVID-19: State of \\ Alarm hingga Lacking Climate di Berbagai \\ Aspek
}

\author{
Firsty Chintya Laksmi Perbawani \\ Program Doktor Ilmu Sosial, Universitas Airlangga
}

\begin{abstract}
ABSTRAK
Tulisan ini membahas bagaimana Spanyol merespons fenomena pandemi COVID-19. Fokus dimulai pada awal kemunculan virus yang mendorong pemerintah mengeluarkan kebijakan dengan empat lokus utama: (1) general confinement atau upaya pelarangan masyarakat keluar rumah; (2) penghentian beberapa kegiatan ekonomi; (3) penyediaan sumber daya kesehatan; dan (4) penyusunan kebijakan mitigasi lanjutan. Penulis melihat pola respon yang terjadi cenderung reaktif daripada antisipatif. Walaupun berbagai langkah strategis sudah dilakukan, hingga akhir Juni 202O, Spanyol gagal membendung kurva sehingga menjadi salah satu negara Eropa terburuk dengan total lebih dari 240.000 kasus. Penulis berargumen faktor kontributornya adalah adanya lacking climate atau iklim serba "kekurangan" di berbagai aspek, sehingga menyebabkan Spanyol menjadi episentrum virus. Kekurangan dapat dilihat secara empiris pada aspek manajemen politis yang asimetris antara pemerintah pusat dengan pemerintah lokal di tujuh belas komunitas otonom; aspek teknologi pengumpulan data yang paradoks; aspek pelayanan kesehatan yang bermasalah; hingga aspek organisasional di tataran Uni Eropa yang mengaburkan fokus Spanyol untuk seharusnya membenahi keadaan nasionalnya terlebih dahulu. Tulisan ini membuktikan bahwa koordinasi menjadi hal yang sangat krusial bagi Spanyol dalam menghadapi krisis kesehatan global, COVID-19.
\end{abstract}

Kata kunci: Spanyol, pandemi, COVID-19, state of alarm, normalitas baru

This paper discusses how Spain has responded to the COVID-19 outbreaks. The focus of discussion began when virus emergences which prompted the government to issue policies with four main focus: (1) general confinement or efforts to prohibit people from leaving the house; (2) cessation of some economic activities; (3) provision of health resources; and (4) preparation of advanced mitigation policies. The author sees that the response pattern tends to be reactive rather than anticipatory. Although various strategic steps have been taken, Spain failed to stem the curve until the end of June 2020. Therefore, it became one of the worst European countries, with more than 240.000 cases. The author argues that the contributing factor is "lacking climate" in various aspects, causing Spain to become the epicenter of the virus. The shortcomings can be seen empirically in the asymmetric characteristics of political management, between the central government and local government in seventeen autonomous communities; paradoxical aspects of data collection technology; problematic aspects of health services; to the organizational part at the level of the European Union which obscures the focus of Spain on what should first fix its national situation. This paper proves that coordination is very crucial for Spain in facing the global health crisis, COVID-19.

Keywords: Spain, pandemic, COVID-19, state of alarm, a new normality 
Kehadiran virus korona atau yang dikenal dengan COVID-19 membawa tantangan tersendiri bagi negara-negara di dunia. Kecepatan dan keefektifan dalam merespons dan memanajemen krisis kesehatan menjadi hal penting. Tulisan ini berfokus pada respons negara Spanyol. Dimulai dengan kasus COVID-19 pertama Spanyol yang ditemukan pada tanggal 31 Januari 2020 dari seorang turis asal Jerman yang saat itu sedang berada di Las Palmas, Kepulauan Canary. Pada 9 Februari 2020 di Palma de Mallorca, Kepulauan Baleares; kasus kedua melibatkan turis asal Inggris di mana sebelumnya memang melakukan kontak dengan turis Perancis yang sudah terlebih dahulu positif COVID-19 (EUFRA 2020, 2). Beberapa fase awal mulai ditemukannya berbagai kasus tersebut menjadikan Kementerian Kesehatan Spanyol memperlebar langkah kerja melalui Coordination of Health Alerts and Emergencies (CCAES). dr. Fernando Simon selaku kepala dari CCAES justru terlihat tenang di hadapan publik, mengatakan pada publik bahwa Spanyol hanya akan mendapat sedikit kasus. Namun yang terjadi, semakin banyak kasus ditemukan di berbagai daerah komunitas otonom (KO) Spanyol. Melihat kenyataan tersebut, dr. Simon yang juga secara otomatis menjadi aktor utama untuk bertanggung jawab mengoordinasikan upaya pencegahan penyebaran virus, bergegas menyediakan tujuh belas layanan telepon yang bertugas memberikan informasi apa pun terkait dengan COVID-19 pada masing-masing KO (Sanchez 2020, 1).

Sejalan dengan apa yang dikatakan oleh dr. Simon, pemerintah pusat Spanyol pun sejak bulan Februari hingga awal Maret selalu menunjukkan sikap tenang dan yakin bahwa penyakit ini tidak akan memberikan dampak yang besar untuk Spanyol (Sanchez 2020, 2). Sikap tersebut semakin mendorong penulis untuk mengatakan bahwa persepsi awal Spanyol terhadap fenomena COVID-19 hanya dinilai sebagai hal yang tidak serius dan tidak akan berdampak besar. Bahkan saat akhir pekan di awal bulan Maret 2020 berbagai kegiatan olahraga dan acara budaya tetap dilakukan. Pada tanggal 8 Maret 2020 pun kegiatan politik seperti demonstrasi untuk memperingati Hari Perempuan Sedunia atau disebut juga dengan Vox party rally (partai terbesar ketiga Spanyol) di Madrid dihadiri setidaknya 120.000 warga. Berlanjut dengan kasus pada KO lainnya, Kementerian Kesehatan Katalonia 
mengkonfirmasi ada dua kematian baru di wilayahnya. Begitu pula KO La Rioja, Murcia, hingga Extremadura dengan total kematian baru di angka 14 dan terus bertambah (Mindler 2020).

Puncaknya pada tanggal 11 Maret 2020, World Health Organization (WHO) mengumumkan bahwa segala peningkatan keadaan darurat kesehatan masyarakat yang diakibatkan oleh COVID-19 dianggap sebagai pandemik berskala internasional (EUFRA 2020, 2). Presiden Pemerintahan atau Perdana Menteri (PM) Spanyol, Pedro Sanchez mendeklarasikan bahwa per tanggal 14 Maret 2020, Spanyol berada pada State of Alarm (estado de alarma) di seluruh entitas teritori nasionalnya. Pernyataan tersebut secara resmi tertulis dalam pasal 116 Konstitusi Spanyol tepatnya pada dokumen Royal Decree 463/2020, khusus untuk menghadapi krisis kesehatan global COVID-19. Konstitusi ini berlaku hingga lima belas hari setelah diberlakukan atau dapat diperpanjang hingga waktu yang ditentukan. Dengan diresmikannya keputusan tersebut, ditetapkan single crisis management command yang dikepalai oleh Menteri Kesehatan (BOE 2020). Selain membahas mengenai keadaan awal dan pandangan Spanyol akan COVID-19, tulisan ini juga mengkaji langkah-langkah strategis apa saja yang dilakukan oleh Pemerintah Spanyol sepanjang krisis hingga akhir Juni 2020. Penulis berargumen, kegagalan Spanyol untuk menekan angka kasus dikarenakan dengan apa yang penulis sebut sebagai lacking climate yakni iklim yang serba "kurang" di berbagai aspek kebijakan Spanyol. Tidak hanya pada salah satu aspek, misal kesehatan saja, namun juga berbagai aspek lain yang akan penulis kaji lebih dalam pada tulisan ini.

\section{Langkah-Langkah Strategis Spanyol}

Setelah mengeluarkan pernyataan bahwa Spanyol berada pada fase State of Alarm, Pemerintah Spanyol mempublikasikan berbagai kebijakan yang diambil untuk mengatasi krisis kesehatan ini. Hal tersebut juga menjawab bahwa langkah strategis yang dilakukan pemerintah Spanyol memiliki pola yang reaktif daripada antisipatif. Berbagai tindakan dilakukan karena sudah 
semakin banyaknya kasus positif dan angka kematian yang terus bertambah akibat COVID-19. Langkah-langkah yang diambil oleh pemerintah Spanyol dapat dikategorikan sebagai berikut: (1) general confinement yang berkaitan dengan pembatasan mobilitas warga dan batas negara; (2) penghentian kegiatan ekonomi; (3) penyediaan sumber daya kesehatan; dan (4) penyusunan kebijakan mitigasi lanjutan.

Pertama, langkah general confinement yang secara otomatis dilakukan sesaat setelah PM Pedro Sanchez mendeklarasikan kondisi negara darurat. Dalam dokumen ofisial yang dipublikasikan oleh Boletin Oficial del Estado (BOE), keberadaan Royal Decree 463/2020 serta pasal 116 dan empat Konstitusi Spanyol memberikan kerangka legitimasi yang jelas bahwa serangkaian tindakan harus diberlakukan untuk mencegah berkembangnya penyakit (BOE 2020a). Langkah pembatasan pergerakan warga selama dalam keadaan darurat, kecuali untuk melakukan bisnis, layanan profesional, maupun berobat. Seluruh aktivitas pendidikan, tidak hanya sekolah formal saja, termasuk pelatihan lainnya baik yang diajarkan oleh institusi negeri maupun swasta; semuanya harus diberhentikan selama fase darurat ini (Rodl 2020, 4). Sedangkan dalam hal batas negara (border), pada tanggal 16 Maret 2020 melalui perintah Kementerian Dalam Negeri INT / 239/2020 pengontrolan batas internal negara kembali diberlakukan. Mereka yang diizinkan untuk memasuki wilayah nasional Spanyol hanya warga dan penduduk Spanyol; pekerja lintas-batas; petugas pengangkut barang yang memasok kebutuhan dasar; maupun mereka yang bisa membuktikan situasi tertentu sehingga dibebaskan masuk ke wilayah negara melalui perjalanan darat. Para pegawai misi diplomatik, kantor konsuler, serta organisasi internasional yang bertempat di Spanyol dibebaskan dari aturan pembebasan ini selama mobilisasi yang mereka lakukan berkaitan dengan pelaksanaan tugas yang dibuktikan dengan surat tugas resmi dari institusi masing-masing (Rodl 2020, 15).

Kedua, penghentian kegiatan ekonomi, utamanya yang melibatkan bertemunya penjual dan pembeli. Seluruh hotel dan tempat akomodasi ditutup, pertokoan dan pariwisata juga ditutup. Namun, 
ada pengecualian yang masih diperbolehkan untuk beroperasi seperti yang berkaitan dengan makanan seperti toserba; kesehatan meliputi klinik, kedokteran hewan, dan apotek; layanan dasar meliputi bank, perusahaan logistik, hingga jalan tol. Di bawah Royal Decree-Law 7/2020, dibahas pula mengenai masalah pajak yang bisa ditangguhkan pembayarannya hingga waktu yang ditentukan karena adanya pandemi COVID-19 ini, dengan syarat besaran pajak tidak lebih dari 30.000 Euro (Rodl 2020, 4). Karena penghentian kegiatan ekonomi ini, pemerintah pusat Spanyol terus melakukan langkah lanjutan dengan terwujudnya Royal Decree 10/2020 pada tanggal 29 Maret 2020. Melalui kebijakan tersebut, pemerintah Spanyol memberlakukan skema recoverable paid leave, perusahaan diwajibkan untuk tetap membayar gaji para karyawannya selama pemberlakuan lockdown atau jarak sosial (BOE 2020b, 1). Skema tersebut dipilih pemerintah pusat Spanyol dengan tujuan mengurangi mobilitas penduduk dan menghentikan aktivitas industri yang tidak penting, melengkapi langkah kebijakan kategori pertama.

Ketiga, langkah penyediaan sumber daya kesehatan. Memiliki National Health System (NHS) atau sistem kesehatan nasional sejak tahun 1986, menjadikan Spanyol sebagai salah satu negara dengan perawatan kesehatan yang sangat berkembang. Bahkan menurut WHO, NHS Spanyol termasuk yang terbaik di dunia. NHS Spanyol memberikan perlindungan universal secara gratis, kecuali untuk obat-obatan yang diresepkan. Sehingga asuransi swasta tambahan dibeli oleh setidaknya $15 \%$ populasi Spanyol, umumnya untuk menjamin perawatan-perawatan kesehatan khusus yang tidak dibiayai oleh pemerintah (Edquist \& MartinezJimenez 2020, 2). Ketika pandemi COVID-19 menyerang, langkah yang strategis diambil oleh PM Sanchez, yang diumumkan pada 18 Maret 2020 bahwa pemerintah telah menasionalisasi semua rumah sakit swasta, rumah sakit militer, dan semua penyedia layanan kesehatan di Spanyol. Menurut data Kementerian Kesehatan Spanyol, setidaknya ada 300 rumah sakit dan klinik swasta di Spanyol yang dinasionalisasikan. Semua penyedia layanan kesehatan sektor swasta tersebut merupakan aktor penting dalam sistem kesehatan Spanyol karena berkualitas sangat baik (IMTJ 2020). Upaya menasionalisasi besar-besaran sektor layanan kesehatan swasta ini diharapkan mampu 
mempercepat penanganan pasien positif dan menekan angka kasus nasional. Tidak hanya itu, Menteri Kesehatan Spanyol, Salvador Illa, menjabarkan langkah strategis lain yakni seluruh mahasiswa kedokteran tahun keempat di Spanyol akan dilibatkan untuk membantu tenaga kesehatan untuk terus memberikan layanan kesehatan yang terbaik. Selain sumber daya tenaga medis, keberadaan perusahaan yang memproduksi peralatan medis juga diharuskan segera menghubungi pemerintah (Payne 2020).

Keempat, menyusun kebijakan mitigasi lanjutan. Mitigasi diartikan sebagai tindakan mengurangi dampak bencana, dalam hal ini krisis kesehatan global akibat COVID-19. Setidaknya ada tujuh Royal Decree yang disetujui pemerintah dari awal state of alarm hingga 7 April dengan tujuan untuk mengurangi kerusakan atau dampak dari sisi ekonomi (Sanchez 2020, 2). PM Pedro Sanchez memutuskan untuk menggerakkan setidaknya 200 miliar Euro atau setara dengan 20\% produk domestik bruto (PDB) Spanyol, dengan perincian 100 miliar Euro dari dana publik; dan 100 miliar bersumber dari swasta. Anggaran tersebut digunakan untuk menekan dampak lanjutan krisis pada aspek ekonomi dengan langkah: memberikan kredit bersubsidi agar likuiditas Usaha Kecil dan Menengah (UKM) dan pengusaha swasta lain tetap terjaga; membayar pasokan dasar air, listrik, dan gas; hingga juga pengurangan iuran atau pajak jaminan sosial bagi perusahaan terdampak COVID-19 yang ingin mempertahankan pegawainya (Sanchez 2020, 2). Penulis melihat langkah keempat sebagai kebijakan yang realistis, karena krisis kesehatan tidak hanya berdampak pada kehidupan manusia (melalui kesehatan) tetapi juga ekonomi.

Pertanyaan analisis selanjutnya adalah tingkat keberhasilan mana yang dicapai oleh Pemerintah Spanyol dalam merespons pandemi. Untuk mengukurnya dapat dilihat dari jumlah kasus yang terkonfirmasi, seperti yang ada pada tabel berikut: 
Tabel 1

Angka Kumulatif Kasus Terkonfirmasi COVID-19 per Juni 2020

\begin{tabular}{|l|r|}
\hline \multicolumn{1}{|c|}{ Negara } & $\begin{array}{r}\text { Jumlah Kasus } \\
\text { (dalam jiwa) }\end{array}$ \\
\hline Brazil & 1.370 .000 \\
\hline Rusia & 641.156 \\
\hline India & 566.840 \\
\hline Britania Raya & 283.541 \\
\hline Peru & 282.365 \\
\hline Chili & 275.999 \\
\hline Spanyol & 249.271 \\
\hline Italia & 240.436 \\
\hline Iran & 225.205 \\
\hline Meksiko & 220.657 \\
\hline
\end{tabular}

Sumber: ECDC (2020)

Berdasarkan tabel resmi yang dikeluarkan oleh European Centre for Disease Prevention and Control (ECDC), hingga 30 Juni 2020, angka kumulatif kasus terkonfirmasi COVID-19 di Spanyol mencapai angka 249.271 (ECDC 2020). Angka tersebut membawa Spanyol menjadi negara dengan kasus terbanyak di antara negaranegara Uni Eropa (UE) dan menduduki negara tertinggi ketujuh di dunia. Hal ini memperkuat argumen penulis untuk dijadikan indikator bahwa pemerintah Spanyol tidak berhasil untuk merespons pandemi.

\section{Lacking Climate Pemerintah Spanyol dalam Manajemen Krisis}

Kegagalan yang ditunjukkan dengan tingginya jumlah kasus yang terjadi di Spanyol dipengaruhi oleh banyak faktor kontributor. Seperti yang telah penulis argumenkan di awal, jika ditilik dengan perspektif yang besar; maka yang paling tepat untuk 
menggambarkannya yakni lacking climate atau iklim yang serba "kurang" di berbagai aspek.

Pertama, pada aspek manajemen politis. Pemerintah Spanyol mengalami lacking in responding pace yaitu terlambat untuk merespons pandemi ini. Spanyol sudah melihat apa yang terjadi di Wuhan, Tiongkok bahkan bagaimana COVID-19 menyebar hingga ke Iran dan Italia. Namun, Spanyol yang tidak berbatasan secara daratan dengan Italia cukup percaya diri bahwa virus ini tidak perlu dikhawatirkan. Pada tanggal 9 Februari 2020, dr. Fernando Simon, kepala CCAES menyampaikan kepada publik bahwa Spanyol hanya akan memiliki sedikit kasus. Tetapi enam minggu kemudian, jumlah kematian per kapita Spanyol sudah tiga kali lipat lebih tinggi daripada Iran; dan empat puluh kali lebih tinggi daripada Tiongkok (Tremlett 2020). Ironi tersebut terjadi karena tidak ada tindakan pelarangan oleh pemerintah pusat. Di Milan, setidaknya 40.000 penonton sepak bola dari Bergamo berkumpul di Stadion San Siro untuk melihat tim kebanggaannya melawan tim dari Valencia. Wali kota Bergamo, Giorgi Gori, mendeskripsikan peristiwa tersebut sebagai "the bomb" yang mampu mengeskalasi angka terjangkit COVID-19 di Bergamo sebanyak 6.728 kasus baru (Giuffrida 2020).

Dalam aspek yang sama, terjadi lacking in alignmenting. Tidak ada keselarasan yang mudah dibangun oleh PM Sanchez. Bahkan saat Spain's Congress of Deputies diselenggarakan oleh PM Sanchez untuk mengajak partai oposisi bersama-sama membuat rencana nasional membangun kembali ekonomi dan keadaan Spanyol karena adanya pandemi; Pablo Casado, pemimpin Popular Party (PP) bersama dengan partai sayap kanan Vox tetap mengecam penanganan pemerintahan Sanchez. Keadaan ini berdasar karena PM Sanchez dan Wakil PM Pablo Iglesias terlalu lamban dalam menilai dampak COVID-19 yang tatarannya sudah menjadi malapetaka nasional. Kenaikan jumlah kasus positif seharusnya dapat ditekan apabila pemerintah mengumumkan state of alarm lebih cepat. Ini menunjukkan adanya ketidakpercayaan antar pihak dalam kongres, pemerintahan sosialis di bawah partai Unidas Podemos yang menaungi PM Sanchez dan Wakil PM Iglesias dinilai tidak kompeten. Terlebih lagi, dengan manajemen politis 
asimetris antara pemerintah pusat dan pemerintah lokal di tiaptiap tujuh belas KO. Pemerintah lokal menolak ketentuan yang sudah ditentukan pemerintah pusat, karena tidak dapat leluasa dan dengan cepat menentukan keputusan saat tiba-tiba ratusan bahkan ribuan kasus baru ditemukan di wilayah otonominya (Hunter 2020).

Kedua, pada aspekpengumpulan data terjadi lacking incontrolling . Saat kondisi pandemi, terjadi paradoks antara kepentingan kolektif untuk menghentikan penyebaran virus atau menjaga hak privasi tiap individu (Paris 2020). Menurut laporan yang dikeluarkan oleh Spanish Data Protection Agency (AEPD) pada 13 Maret lalu, pemerintah Spanyol tetap menjaga privasi data pribadi masyarakat sesuai dengan batasan-batasan hukum yang sudah ada dalam pasal lima General Data Protection Regulation (GDPR). Namun situasi berbeda dilaporkan oleh EUFRA, pemerintah pusat Spanyol dinilai tidak dapat mengontrol inisiatif teknologi tertentu. Seperti kekhawatiran yang ditimbulkan Covidapp yang diluncurkan oleh pemerintah lokal KO Madrid di mana mencatat informasi pribadi bahkan nomor kartu identitas nasional (DNI) ataupun foreigner's identity number (NIE). Pada 18 Maret 2020, pemerintah KO Katalonia juga meluncurkan aplikasi seluler "StopCOVID-19Cat" yang juga menimbulkan keraguan akan perlindungan informasi pribadi warga (EUFRA 2020, 8-9). Hal tersebut menunjukkan bahwa pemerintah tidak dapat mengontrol dengan baik. Tidak hanya itu, collapse of detection atau deteksi data awal yang sangat berantakan juga menjadi faktor kontributor PM Sanchez terlambat untuk mengumumkan state of alarm. Platform sistem komputer "SiVies" di bawah National Center for Epidemiology (CNE) juga kurang memadai, misal dari hampir 10.000 kasus hanya 700 yang masuk ke database; dalam artian hanya 8\% saja. Spanyol juga mengalami a black week of official data yakni pada kurun waktu 27 Mei hingga 3 Juni yang menunjukkan total kenaikan kematian hanya sepuluh saja (Llaneras 2020). Ini menunjukkan betapa buruknya metode pengumpulan data Spanyol dengan banyaknya ketidakakuratan. Data menjadi hal krusial saat terjadi pandemi, berbagai disinformasi mampu memicu collective paranoia (ketidakpercayaan bersama), kebingungan, hingga ketakutan (EUFRA 2020, 9). Dampak-dampak tersebut mampu merusak keefektifan tindakan pemerintah Spanyol untuk mencegah 
penyebaran COVID-19.

Ketiga, pada aspek kesehatan. Pemerintah Spanyol mengalami lacking in providing. Kegagalan untuk menyediakan alat tes deteksi awal COVID-19, hingga kekurangan alat pelindung diri (APD) seperti masker, baju medis, hingga sarung tangan. Tenaga medis pun juga menjadi aktor krusial yang rentan terinfeksi. Hingga 3 April 2020, angka tenaga medis yang terinfeksi mencapai 25.000 jiwa atau $15 \%$ dari total kasus terkonfirmasi (Sanchez 2020, 2). Menteri Kesehatan Salvador Illa mengatakan apabila sebelum pandemi, pengaturan kebutuhan kesehatan dan kinerja rumah sakit ada di bawah wewenang pemerintah lokal tiap KO, maka sekarang semua harus diatur oleh pemerintah pusat. Namun tiap daerah memiliki menolak dengan alasan, jumlah kasus yang berbeda. KO Madrid yang menjadi episentrum virus harus mendapati fakta lonjakan hingga tiga kali lebih banyak dalam sehari saja, Unit Perawatan Intensif (ICU) harus tetap beroperasi walaupun dengan alat yang terbatas (NYT News 2020). Ini menunjukkan ketidakmampuan pemerintah untuk menyediakan akses pelayanan medis yang baik, sekalipun NHS Spanyol menjadi salah satu yang terbaik di dunia.

Keempat, pada aspek organisasional, Spanyol menghadapi lacking in prioritizing. Dalam tataran UE, Spanyol dengan negara-negara di Selatan lain seperti Italia dan Prancis selalu mendahulukan usaha menyerukan perlunya solidaritas antar negara anggota. Seruan tersebut ditujukan kepada negara-negara di Utara seperti Jerman dan Belanda yang secara ekonomi lebih baik. Tetapi ketakutan terjadi apabila upaya solidaritas nantinya akan dirusak oleh berbagai kebijakan yang tidak efektif (Sanchez 2020, 2). Sebagai contoh, adanya krisis finansial di tahun 2008, Spanyol harus mengalami lonjakan pengangguran setidaknya 27\%, utang publik, hingga resesi yang sangat drastis. Toni Roldan (dalam Tremlett 2020) seorang ekonom mengalkulasi setidaknya Spanyol membutuhkan pinjaman dari European Stability Mechanism (ESM) sebesar 200 miliar Euro untuk memulihkan keadaan, bahkan skenario ini bisa menjadi lebih buruk karena adanya pandemi. Hal tersebut yang penulis maksud dengan derajat prioritas; di mana seharusnya fokus Spanyol adalah membenahi 
fungsi pemerintahan bukan bergantung diri atas nama solidaritas organisasi UE. Dapat dilihat bagaimana "lacking climate" pada keempat aspek di atas mampu dijadikan sebagai faktor kontributor yang memperkuat argumen penulis bahwa Spanyol gagal dalam merespons pandemi.

\section{Respons Lanjutan: a New Normality?}

Pada penghujung bulan yakni 20 Juni 2020 atau tiga bulan setelah pemerintah mengumumkan State of Alarm, fase ini secara resmi dicabut. PM Pedro Sanchez tetap menghimbau masyarakat untuk tidak meremehkan protokol kesehatan yang harus dipatuhi walaupun pemerintah sudah menurunkan fase kedaruratan pandemi. Penggunaan masker dan jaga jarak antar warga setidaknya 1,5 meter sudah menjadi kewajiban yang wajib dilakukan setiap warga bepergian ke luar rumah. Dalam pidatonya, PM Sanchez juga mengatakan dengan bangga bahwa State of Alarm terbukti mampu menyelamatkan 450.00o jiwa di Spanyol (McMurty 2020). Dengan diakhirinya fase tersebut, kebijakan untuk membuka kembali perbatasan bagi warga yang berasal dari negara-negara anggota UE, Britania Raya, serta negara Schengen mulai diberlakukan. Begitu pula dengan kebijakan bahwa masingmasing KO bisa mengambil alih wewenang pemerintah pusat kembali untuk membuat peraturan New Normality yang sesuai dengan kondisi daerahnya.

Pemerintah lokal Andalusia masih terus mengalkulasi situasi, seperti membatasi kapasitas pengunjung hotel dan akomodasi lainnya 50\% saja, kolam renang umum $75 \%$, hingga konser di luar ruangan hanya boleh dihadiri 1.500 penonton saja. Hampir sama, yakni di Aragon, pemerintah lokal membatasi pengunjung klub malam dan bar setengah dari jumlah normalnya dengan catatan tidak ada lantai dansa. Bahkan berbagai pesta lokal pun ditunda hingga 30 September mendatang. Wilayah Asturias pun juga masih memberlakukan pembatasan waktu berkunjung di pantai hingga sore hari saja. Taman bermain anak pun sudah dibuka, sabun pembersih tangan disediakan oleh pemerintah. Berbeda 
dengan wilayah KOC sebelumnya, Cantabria baru memberlakukan new normality sepekan kemudian dengan kapasitas yang jauh lebih sedikit. Tempat wisata alam hanya boleh 30 pengunjung saja, acara olahraga hanya 300 orang saja, bahkan pernikahan dibatasi 150 tamu undangan apabila dilakukan di dalam ruangan. Castile-La Mancha dan Castile-Leon memberlakukan kebijakan yang cukup rata yakni semua wilayah hanya dibuka $75 \%$ saja. Extremadura justru memberlakukan new lockdowns dalam dua fase, yakni di fase pertama yang akan terus dilakukan hingga 31 Juli, dan fase kedua dilakukan dengan menunggu perkembangan situasi lanjutan. Keputusan ini diambil oleh pemerintah KO Extremadura karena banyaknya kasus baru di wilayahnya. Galicia cenderung positif untuk melakukan normalisasi baru bertahap selama sepekan ke depan, dengan gradual 30\% menuju 75\% dari kapasitas normalnya (Guell 2020).

Sedangkan, KO Katalonia sangat terbuka dengan kebebasan individu di wilayahnya. Kepala Kesehatan Daerah, Alba Berges, mengatakan bahwa pembatasan kapasitas tidak penting, namun yang penting adalah individual responsibility. Hal tersebut dapat diwujudkan apabila tiap individu patuh untuk menggunakan masker tanpa dipaksa oleh pemerintah (McMurty 2020). Berbeda dengan pemerintah Kepulauan Baleares, La Rioja, dan Kepulauan Canary yang masih membatasi kapasitas pengunjung serta menunda pesta lokal. Begitu pun dengan wilayah Madrid yang jauh lebih ketat dan ternyata masih melanjutkan lockdown karena jumlah kasus yang masih bertambah. Pemerintah lokal Murcia, Navarre, dan daerah Valencia masih melakukan fase kalkulasi lanjutan, protokol kesehatan tetap dilanjutkan. Pemerintah setempat juga tidak ragu untuk membatalkan pesta lari banteng Sanfermines yang cukup terkenal di dunia karena adanya COVID ini. Terakhir, wilayah Pais Vasco atau Basque Country mengatakan pembatasan di area olahraga yakni empat meter persegi per orang (Guell 2020). Beragam kalkulasi dan analisis yang dilakukan masing-masing pemerintah otonom di Spanyol ini bisa ditilik lebih dalam untuk menghitung keefektifan pola penanganan krisis kesehatan di kemudian hari. 


\section{Simpulan}

Penulis menyimpulkan bahwa pemerintah Spanyol memberi respons awal yang lamban. Sikap cukup percaya diri bahwa hanya akan sedikit kasus COVID-19 yang ditemukan, menjadi bumerang bagi pemerintahan PM Pedro Sanchez. Sehingga baru pada 14 Maret 2020 di bawah Royal Decree 463/2020, dinyatakan bahwa Spanyol berada dalam state of alarm. Pola responsnya pun cenderung reaktif karena semakin banyaknya kematian di tujuh belas komunitas otonominya. Dengan diberlakukannya state of alarm, berarti langkah-langkah strategis juga diambil oleh pemerintah. Adanya lockdown yang begitu ketat dan social distancing; diberhentikannya aktivitas ekonomi; penyediaan pelayanan kesehatan dan kebutuhan medis; hingga berbagai kebijakan mitigasi lanjutan. Namun, ini tetap membawa Spanyol menjadi negara Uni Eropa dengan jumlah kasus tertinggi mencapai 240.00o kasus yang menunjukkan adanya kegagalan dalam merespons pandemi.

Faktor kontributor mengapa kegagalan bisa terjadi di Spanyol yakni adanya "lacking climate" atau kekurangan di berbagai aspek antara lain: (1) aspek manajemen politis terjadi lacking in responding pace karena respons yang terlambat, juga lacking in alignmenting karena tidak selarasnya kerangka kerja yang diinginkan pemerintah pusat dan pemerintah lokal di masingmasing KO; (2) aspek teknologi pengumpulan data terjadi lacking in controlling karena data yang masuk pada sistem komputasi SiVies tidak akurat sehingga ketidakpercayaan dan collective paranoia hadir di tengah masyarakat; (3) aspek kesehatan terjadi lacking in providing akan kebutuhan alat pelindung diri dan tingginya angka pekerja medis yang juga terinfeksi; serta (4) aspek organisasional terjadi lacking in prioritizing yang mengantungkan diri menyerukan solidaritas UE untuk membantu secara finansial padahal yang harus didahulukan saat krisis kesehatan adalah perbaikan pemerintahan internal Spanyol. Kegagalan untuk menekan angka kasus; terlebih lagi dengan adanya new normality yang mulai dilakukan tiap-tiap komunitas otonom Spanyol tidak menutup kemungkinan akan munculnya second wave atau gelombang kedua lonjakan krisis COVID-19. Untuk itu, penulis 
harapkan ada kajian lebih lanjut untuk menggambarkan apa yang terjadi di Spanyol berikutnya.

\section{Referensi}

\section{Jurnal dan Jurnal Daring}

Edquist, Kristin \& Martinez-Jiminez, Mario. 2020. “Spain's policy response to the novel coronavirus and COVID-19". Eastern Washington University, 2020.

EUFRA. 2020. "Coronavirus COVID-19 outbreak in the EU Fundamental Rights Implications". University Institute of Migration Studies, 2020.

Rodl. 2020. "Measures taken by the Government of Spain against the health alert caused by COVID-19". Rodl \& Partner, 2020.

Sanchez, Fernando Jimenez. 2020. "The Political Management of the Covid-19 Crisis in Spain”. Gerer le Covid-19, Un tour d'Europe, Foundation Robert Schuman, 2020.

\section{Artikel Daring}

ECDC. 2020. "Coronavirus Pandemic (COVID-19)". [daring] dalam https://ourworldindata.org/coronavirus [diakses pada 3 Agustus 2020]

Giuffrida, Angela. 2020. "Bergamo mayor says football match escalated infections in Italian province" [daring] dalam https://www.theguardian.com/world/2020/mar/24/ bergamo-mayor-says-football-match-escalatedcoronavirus-infections-italian-province [diakses pada 2 
Agustus 2020]

Guell, Oriol. 2020. "Spain's new normality: The new rules, region by region" [daring]dalam https://english.elpais.com/ spanish news/2020-06-21/spains-new-normality-thenew-rules-region-by-region.html [diakses pada 9 Agustus 2020]

Hunter, Simon. 2020. "Spanish PM secures support to extend state of alarm after fierce criticsm in Congress" [daring] dalam https://english.elpais.com/politics/2020-04-23/spanishpm-secures-support-to-extend-state-of-alarm-afterfierce-opposition-criticism-in-congress.html [diakses pada 7 Agustus 2020]

IMTJ. 2020. "Covid-19: Spain Nationalises Private Healthcare” [daring] dalam https://www.imtj.com/news/covid-19spain-nationalises-private-healthcare/ [diakses pada 29 Juli 2020]

Llaneras, Kiko. 2020. “Theproblems Spain's outdated data methods have caused during a 21st-century pandemic" [daring] dalam https://english.elpais.com/society/2020-06-24/ the-problems-spains-outdated-data-methods-havecaused-during-a-21st-century-pandemic.html [diakses pada 7 Agustus 2020]

McMurty, Alyssa. 2020. "COVID-19: Spain bids farewell to state of alarm” [daring] dalam https://www.aa.com.tr/en/europe/ covid-19-spain-bids-farewell-to-state-of-alarm/1884211 [diakses pada 9 Agustus 2020]

Paris, Maurico. 2020. "Privacy and COVID-19: An Orwellian paranoia?" [daring] dalam https://ecija.com/en/salade-prensa/costa-rica-privacy-and-covid-19-an-orwellianparanoia/ [diakses pada 7 Agustus 2020]

Payne, Adam. 2020. "Spain has nationalized all of its private hospitals as the country goes into coronavirus lockdown" 
[daring] dalam https://www.businessinsider.com/ coronavirus-spain-nationalises-private-hospitalsemergency-covid-19-lockdown-2020-3? $\mathrm{r}=\mathrm{US} \& I R=\mathrm{T}$ [diakses pada 29 Juli 2020]

Tremlett, Giles. 2020. "How did Spain get its coronavirus response so wrong?" [daring] dalam https://www.theguardian. com/world $/ 2020 / \mathrm{mar} / 26 /$ spain-coronavirus-responseanalysis [diakses 2 Agustus 2020]

Ward, Alex. 2020. "How Spain's coronavirus outbreaks got so bad so fast". [daring] dalam https://www.vox. com/2020/3/20/21183315/coronavirus-spain-outbreakcases-tests [diakses pada 29 Juli 2020]

\section{Lain-lain}

BOE. 2020a. "Real Decreto 463/2020, de 14 de marzo". [online] dalam https://www.boe.es/buscar/act. php?id=BOE-A-2020-3692 [diakses pada 13 Juli 2020]

BOE. 2020b. "Real Decreto-ley 7/2020". [online] dalam https://www.boe.es/boe/dias/2020/03/13/pdfs/ BOE-A-2020-3580.pdf [diakses pada 13 Juli 2020]

NYT News. 2020. Spain's Health Care Workers are Battling Coronavirus, Unprotected. Here's How. [video] dalam https://www.youtube.com/watch? $v=i 4$ DngwmTzIA [diakses pada 8 Agustus 2020] 